\title{
PUBLIC-PRIVATE PARTNERSHIP IN TERMS OF THE CONTRACT FOR THE CONSTRUCTION OF DISTRICT HOSPITAL IN ŻYWIEC AS AN EXAMPLE OF OPTIMIZATION IN THE PUBLIC INTEREST
}

\author{
KRYSTIAN JASZCZYK ${ }^{1}$
}

\begin{abstract}
The implementation, including financing, of public tasks is not an easy venture. In some situations, public entities are not capable of bearing the costs of this type of investment. The inability to finance such needs from public funds is becoming the main reason for public entities to turn attention to the private sector and its funds in order to finance public needs using public-private partnerships. The objective of the article is to evaluate the public-private partnership as an institution for optimization of public spending on the example of a contract for the construction of a District Hospital in Żywiec. The research problem is the answer to the question whether the institution of public-private partnership serves the public interest through the optimization of public spending. According to the research hypothesis, the currently functioning public-private partnership is a legal solution optimizing public expenditure for benefit of the public interest. The article presents the way of functioning and financing of public-private partnership on the example of a contract for the construction of a District Hospital in Żywiec. The subject was chosen because of its relevance. The Polish legislator, while defining public tasks for their implementation and the requirements for their fulfillment, forgets that public entities are not always willing to carry out these tasks themselves and assume the risk which accompanies their implementation.
\end{abstract}

\section{Keywords}

Public-private partnership; public entity; private partner; District Hospital in Żywiec JEL Classification: H51, H41, H60

1 Ph.D. Student at the Department of Public Financial and Financial Law, Faculty of Law, University of Bialystok, Poland. The author specializes in the public-private partnership. He is a member of Information and Organization Center for the Research on the Public Finances and Tax Law in the Countries of Centre of Eastern Europe. Contact email: jaszczykkrystian@wp.pl. 


\section{Introduction}

The public-private partnership (PPP) in Poland is regulated by the Act of 19 December 2008 on public-private partnership. According to Art. 1/1 of PublicPrivate Partnership Act, the objective of the act is to formulate principles of cooperation between public entity and private partner within the PPP. Therefore, the Act will be applied to any cooperation of public and private entities, providing that legal definition of PPP is fulfilled as presented in Art. 1/2 of Public-Private Partnership Act. This is aimed at providing transparency, competitiveness and equal access to all entities involved in such projects (Partnerstwo publiczno-prywatne, 2010: 32).

According to Art. 1/2 of Public-Private Partnership Act, the subject of PPP is joint execution of venture based on division of tasks and risks between public entity and private partner. The aforementioned regulation indicates the subjective scope of PPP, which includes both public entity and the private partner. The legislator emphasizes that the cooperation takes form of a joint venture based on division of tasks. A characteristic feature of PPP is division of risk between public entity and private partner. According to the legislator, PPP is to be a cooperation of two sectors: public sector, whose objective is to execute public tasks, and private sector, aimed at profit.

Due to framework character of Public-Private Partnership Act, no specific division of tasks between the public entity and private partner is enforced. Such legislative measure allows this issue to be resolved by the partners, so that individual tasks may be assigned to each party efficiently and in accordance with subject of the partnership as well as competences and capabilities.

The next element of public-private partnership is division of risk between public entity and private partner. Notably, no legal definition of risk exists, hence linguistic definition should be used. "Risk is probability, possibility that something will not work, presumed effects will not be achieved or circumstances will occur hindering achieving of the goal" (Dyczkowski, 1998: 1521). The legislation also does not specify what kinds of risk exist. Similarly to the division of tasks, the legislator does not enforce any form of risk division, leaving this matter to the involved parties. Importantly, the division of risk is one of the obligatory criteria used for assessment of offers in process of selection of the private partner.

The subsequent step in PPP is the division of tasks. PPP aims at entrusting private partner with some tasks to perform. The legislation does not indicate what tasks are to be entrusted within the public-private partnership. Since public entities are assigned with the realization of public tasks, it is clear that only tasks within this 
Public-Private Partnership in Terms of the Contract for the Construction of District...

scope may be entrusted to the private partners, hence ventures executed within PPP are public tasks.

The subject of PPP is cooperation of public entity and private partner (PublicPrivate Partnership Act, Art. 1/1). As an effect, the concept of the public entity is of great significance for determination of the range of application of Act on publicprivate partnership in terms of subjective scope.

According to Art. 2/1 of Public-Private Partnership Act, public entities include: a) unit of public finance sector as indicated in Act of 27 August 2009 on Public Finance or b) different than specified in letter (a) legal entity created specifically in order to satisfy general needs which do not have industrial of trading character, if entities indicated in letter (a) either finance over $50 \%$ of this entity, possess over a half of shares, maintain oversight of management authority or have right to appoint over half of management or oversight authorities, either individually or jointly, directly or indirectly through other entities; c) associations of entities indicated in letters (a) and (b).

According to Art. 2/2 of Public-Private Partnership Act, the private partner should be interpreted as the entrepreneur or foreign entrepreneur. The mentioned regulation does not include any definition of the entrepreneur, nor does it refer to any other regulation defining the term. The explanatory memorandum also does not contain any such information.

For this purpose, regulations contained in Act of 2 July 2004 on Freedom of Economic Activity should be applied, as they include the definition of entrepreneur. According to Art. 4/1 of Freedom of Economic Activity Act, "The entrepreneur in the meaning of the Act is a natural person, the legal person and unincorporated organizational unit without legal personality, which is given legal capability by a separate act, running the business on their own behalf". Moreover, according to Art. 4/2 of Freedom of Economic Activity Act, also "as an entrepreneur may also be considered a partner of a civil partnership to the degree of their economic activity". Furthermore, according to Art. 2 of Freedom of Economic Activity Act, economic activity is "(...) any gainful activity involving manufacturing, construction, trading, services as well as surveying, exploration, and extraction of mineral resources performed in an organized and constant manner".

Additionally, Freedom of Economic Activity Act also contains the definition of foreign entrepreneur. This is of fundamental significance from the PPP standpoint, since, according to Art. 2/2 of Public-Private Partnership Act, the foreign entrepreneur may also be the private partner. In this case, proper regulation defining this term is the aforementioned Freedom of Economic Activity Act. This is also confirmed by explanatory memorandum to Public-Private Partnership Act, 
according to which "private partner may also be a foreign entrepreneur, as defined by Art. 5/3 of Act of 2 July 2004 on freedom of economic Activity" (Draft no. 1180: 9). According to Art. 5/3 of Freedom of Economic Activity Act, the foreign entrepreneur is a foreign person, i.e. natural person who is not citizen of Poland, legal person with their registered office located abroad or an unincorporated organisational unit without legal personality but with legal capabilities with their registered office located abroad, performing their economic activities beyond Polish borders.

The public-private partnership is open to any fields and forms of services which, according to existing law, should be provided by public entities. This allows for the realization of projects in such fields as education, healthcare, infrastructure, etc.

In Art. 1/2 of Public-Private Partnership Act, legislator indicated that the subject of cooperation within the public-private partnership is the execution of venture, whereas, according to Art. 2/4 of this act, the subject of the venture may be:

1. construction or renovation of building development,

2. provision of services,

3. performing work, particularly equipping asset with device improving its value or utility,

4. another service.

The aforementioned activities should be combined with maintenance or management of the asset used for the realization of public-private venture or connected therewith. Such definition of the venture is a purposeful act on behalf of the legislator, aimed at encompassing all significant fields of cooperation between public entities and private partners as broadly as possible (Draft no. 1180: 10).

Activities of maintenance and management may be connected to the responsibility of undertaking expenditures, both necessary and those increasing utility of the asset, placed on the private partner. Detailed scope of maintenance and management of the asset should be determined by the contract of public-private partnership. Such contract should also determine the precise division of tasks and costs connected to these activities.

The objective of the article is to evaluate the public-private partnership as an institution for optimization of public spending on the example of a contract for the construction of a District Hospital in Żywiec. The research problem is the answer to the question whether the institution of public-private partnership serves the public interest through the optimization of public spending. According to the research hypothesis, the currently functioning public-private partnership is a legal solution optimizing public expenditure for benefit of the public interest. According to the 
Public-Private Partnership in Terms of the Contract for the Construction of District...

research hypothesis, the currently functioning public-private partnership is a legal solution optimizing public expenditure for benefit of the public interest. The article presents the way of functioning and financing of public-private partnership on the example of a contract for the construction of a District Hospital in Żywiec.

\section{Construction of the New Building of District Hospital in Żywiec}

During analysis of the construction of District Hospital in Żywiec, it should be noted that tasks referring to investments in hospitals are the responsibility of powiat (district) authorities in accordance with Art. 4/1 of Act of 5 June 1998 on District Government. Public-private partnership project presented in this paper is the first example in Poland, where Starost's Office can perform public tasks, such as health care and promotion, despite lack of funds for investments. Private partner selected for the presented project - InterHealth Canada Limited - is to design, finance and construct the hospital. Subsequently, for the next 30 years, the company will manage the hospital, including providing of medical services available to all, regardless of their income and status, based on contracts with National Health Fund (Herbst, Jadach-Sepioło, 2012: 6). For this purpose, Starost's Office in Żywiec adopted a resolution on building the new hospital in form of $\mathrm{PPP}^{2}$.

One of the important aspects of this investment is ensuring of transfer of knowledge (know-how) $)^{3}$ on construction of modern medical facilities and their long-term management, particularly in respect of fulfilling the requirements for medical facilities outlined in decree of the Minister of Health of 2 February 2011 on professional and sanitary requirements placed on premises and equipment in healthcare facilities ${ }^{4}$. In terms of adapting facilities to needs of people with disabilities, installation of modern sanitary equipment and designating new utility rooms, the most common problem is lack of sufficient funds for such purposes. In case of District Hospital in Żywiec, premises and technical conditions forced the decision on constructing modern medical complex and revitalization of facilities currently in use after completion of investment ${ }^{5}$. Providing new hospital building opened new possibilities of organization of available space, for instance, construction of landing platform for emergency helicopters as well as the creation

2 By resolutions of District Council in Żywiec no. XXXV/317/09 and no. XLIII/401/2010.

3 Know-how - operational knowledge, referring to people's abilities, means one's ability to perform an action. It is contained in person's mind and associated with experience (Bayer, 2011: 14).

4 Decree of the Minister of Health of 2 February 2011 on professional and sanitary requirements placed on premises and equipment in healthcare facilities.

5 Building of Żywiec hospital was constructed in 1888-1991. Due to their technical condition, the thorough renovation was required. The cost of such renovation would exceed that of constructing the new building. Moreover, some of the hospital buildings are in the register of objects of cultural heritage, which limits possibilities of adapting them for the modern healthcare facility. 
of new wards and development of existing ones, such as geriatrics, surgery (Herbst, Jadach-Sepioło, 2012: 6).

By realizing the investment through the public-private partnership, Starost's Office in Żywiec developed venture model DBOD (design, build, operate, deliver) as a response to needs of the medical facility.

For the private partner, InterHealth Canada Limited was selected, the company established in 1994, specializing in developing, launching and managing of healthcare facilities (www.interhealthcanada.com). As a result of this venture, modern hospital buildings and systems for providing healthcare services will be created, which will be subjected to assessment of key performance indicators (KPI) specified in partnership contract through internal control and external audits. According to concept project ${ }^{6}$, District Hospital in Żywiec will have 8 wards on 4 floors and a total space of over 24 thousand sqm. The hospital complex will include, among others, surgery ward integrated with other wards, the emergency ward with landing platform for helicopters and additional clinics (www.starostwo.zywiec.pl). The hospital will be managed by InterHealth Canada. Sixteen months before the completion of construction, the private partner will assume management of existing District Hospital, which will be transformed into the geriatric center (Herbst, JadachSepioło, 2012: 8).

According to the partnership contract, private partner is to provide equal access to the services for all residents of the district. The operation will be financed by National Health Fund, and thus should be available to all patients covered by health insurance. I order to ensure high quality of provided medical services, cooperation with public entity will be required (Herbst, Jadach-Sepioło, 2012: 8).

According to this report, lack of public consultations during the selection of the location of investment was an obstruction for execution of public-private partnership, which led to opposition from residents of the town and district to decisions made by Starost's Office. The opposition raised arguments on issues with access due to lack of a bridge, necessity of commuting through the large part of town and local topography (Herbst, Jadach-Sepioło, 2012: 8).

\section{Financing in PPP on the Example of Construction of District Hospital in Żywiec}

In the public-private partnership, it is the private partner who is supposed to provide funds for the venture in total or in part or ensure financing by third parties. This

6 Acceptance of concept project completed the first stage of architectural and engineering works, which were started after signing the contract of investment in form of PPP on 15 September 2011. 
includes all expenses, starting with investments (e.g. construction or renovation of the building, adapting infrastructure to fulfill certain functions), later followed by exploitation expenditures, i.e. maintenance and management of the project. Private partner is obligated to finance at least part of the venture, otherwise, the contract will not constitute public-private partnership (Partnerstwo publiczno-prywatne, 2010: 42). Funds for the financing of given venture may belong to private partner or come from credit, loan, subsidy or issuance of shares. In certain cases, the private partner may use bank promissory note. In such cases contract may be signed conditionally with the determination of the date of obtaining said note, signing credit contract, receiving subsidies, issuance of shares, buyback of debts etc. (Gonet, 2009: 54).

In terms of realization of PPP projects, sources of financing may be divided into two groups, namely returnable and non-returnable funds. Non-returnable funds include funds from European Union and supplementary sources of financing, use of which is dependent on the position of potential creditors. Involvement of authorities is frequently expanded to include guarantees required by creditors. Depending on the degree of realization of the project, private capital may take the form of sponsored capital and bank credits, contracts for provision and sale of services and funds obtained through trading in capital market instruments. On the other hand, the aforementioned returnable funds constitute a significant share of financing of infrastructural projects. This category contains bonds, leasing and subordinated debt. However, the important role is that of credits granted by the banks, groups of banks and multilateral financial institutions, e.g. World Bank Group (Brzozowska, 2006: 81-83).

With regard to the issue of financing of the construction of District Hospital in Żywiec, private partner designs and constructs the object, and subsequently manages the hospital, providing medical services and covering all associated costs. Value of this venture is estimated at 220 million PLN. The private partner will be able to retrieve invested funds through contracts with NFZ as well as through potential commercial medical services.

In case of construction of District Hospital in Żywiec, private partner takes three fundamental risks - those of construction, availability, and demand. The demand risk is of the greatest threat to the project due to the existing system of financing medical services. NFZ - the public entity paying for medical services operates on the basis of one-year orders and maximally three-year long contracts. Private partner does not have any guarantees of financing in long-term, whereas PPP contracts are signed for 20-30 years. This issue may fully manifest already at the stage of credit application. 
A report was created by Ministry of Regional Development containing conclusions from the selection of private partner in Żywiec, which indicated several key issues:

- the capability of public entities to provide guarantees and, hence, the necessity of unequivocal regulation of qualification of liabilities resulting from provided guarantees;

- lack of binding commitments from financing institutions pertaining to assurance of project financing;

- difficulties with assessment of partner reliability;

- the capability of covering costs of project monitoring by the private partner (Urbanowski et al.: 2011).

The notes presented above are general in character and are not directly connected to the project of construction of medical facilities. They do, however, present the certain aspect of difficulties in the preparation of public-private partnership ventures, namely way to completion of the venture in terms of financing.

As has been mentioned above, medical services within described PPP project will be financed by NFZ based on the contract signed with District Hospital in Żywiec. However, the risk exists that such contract may not be signed. In such case, Starost's Office will be obligated to undertake actions towards finding new sources of financing and covering costs of offered medical services. Such situation may threaten the public interest and, subsequently, lead to increase in public spending.

In order to secure the public interest of Starost's Office in Żywiec, it may reasonable to appoint the special committee that can analyze reasons of why the contract between medical facility and NFZ was not signed. Such body may be appointed pursuant to Art. 17/1 of District Government Act, according to which the District Council may appoint permanent and temporary committees for specific tasks, determining the subject of their operation and composition. These committees report to the District Council in the entire scope of their operation, present plans, and accounts of their functioning. The purpose of such committee may also be oversight of the process of applying for contracts with NFZ conducted by the healthcare facility. Such solution would contribute to securing the public interest of local authorities in longer perspective of the functioning of described public-private partnership.

Furthermore, the possibility exists of applying Art. 145/1 of Act of 29 January 2004 on public procurement, according to which "In case of significant change of circumstances causing the conclusion of contract to no longer contribute to public interest, which could not have been forecasted when entering into agreement, or if further execution of contract may threaten important interest of national security 
Public-Private Partnership in Terms of the Contract for the Construction of District...

or public security, contracting entity may cancel the contract within 30 days from the time at which these circumstances were identified". Presented Article grants the right of unilateral withdrawal from the contract as a result of particular circumstances only to the contracting entity. This is undoubtedly a deviation from the principle of equality of parties involved in contract existing in civil law and is considered a special right, independent from the right of both parties pursuant to Civil Code (e.g. Arts. 491-493).

A solution to this problem within the scope of existing system of financing medical services may be a system of basic hospital guarantee of healthcare services introduced as legal institution by amendment to Act of 27 April 2008 on Health Care Services Financed by Public Funds, i.e. Act of 23 March 2017 on amending the Act on Health Care Services Financed by Public Funds, which created a "network of hospitals".

\section{Network of Hospitals}

The legislator's premise in the amendment of Act of 27 April 2008 on Health Care Services Financed by Public Funds is to create a "network of hospitals" which is operating since 1 October 2017. Moreover, the amendment to Health Care Services Financed by Public Funds Act changes rules of financing services within hospital treatment and, partially, also within specialist out-patient care.

The aim of the amendment to Health Care Services Financed by Public Funds Act is stabilization of structure and financing of hospitals. Amendment introduces new legal institution - the system of basic hospital guarantee of healthcare services (PSZ) which should be the main form of guaranteeing access to healthcare services within hospital treatment. As part of PSZ, healthcare facilities in given voivodship will be classified into one of 6 levels of service guarantees (Draft no. 1322: 4). Following levels of service guaranteeing were specified (Health Care Services Financed by Public Funds Act, Art. 95/2): hospitals of I, II and III degree, oncologic or pulmonological hospitals, pediatric hospitals, and national hospitals. These levels of guarantee form the network of hospitals. Pursuant to Art. 95m/1 of Health Care Services Financed by Public Funds Act, the healthcare provider is classified within the system for four years, in terms of the healthcare facility as indicated by regulations on healthcare activity conducted in given voivodship. Considering Art. $95 \mathrm{~m} / 2$ of Health Care Services Financed by Public Funds Act, it should be remembered that classification within the guarantee system involves including given healthcare provider in one of the levels of this system as well as indicating profiles of the system, scope, and forms of treatment, within which the guaranteed healthcare services will be provided. 
According to Art. 95n of Health Care Services Financed by Public Funds Act, director of respective voivodship department of NFZ creates and publishes in Public Information Bulletin a list of healthcare providers classified in guarantee system with indication of all of the profiles of the system as well as scopes and additional forms, within which they will provide healthcare services as part of the system. The list for given voivodship is published no later than 27 March with duration of 4 years and comes into effect on 1 July. The only exception is the first list, which was to be published no later than 27 June 2017 and remains in effect from 1 October 2017 to 30 June 2021.

According to the assessment of effects of regulation, ca. 93\% of total budget for hospital treatment will be assigned to finance services within PSZ. Moreover, aside from contracts for healthcare services provided within the guarantee system, the previous mechanism of contracting medical services based on competitive bids or negotiations will be also functioning. This means that hospitals not classified within the guarantee system will also be able to accept patients as part of the contract with the NFZ. Applications for contracts will still be possible through entering announced competition. According to Art. 136c/1 of Health Care Services Financed by Public Funds Act, healthcare services provided based on contract within PSZ are to be financed in form of flat-rate payment from guarantee system. Basing on Art. 136c/2 of Health Care Services Financed by Public Funds Act, the size of this payment is to be determined for reference period specified in the contract, not longer than a calendar year.

The Act on amending the Health Care Services Financed by Public Funds Act came into effect on 4 May 2017, whereas the network of hospitals started its operation on 1 October 2017. Transitional provisions contained in this amendment should also be mentioned here, as they carried significance for existing healthcare providers. Existing contracts for services within PSZ were extended to 30 September 2017. After that day, i.e. starting on 1 October 2017, these services were integrated into PSZ with the provision, that healthcare providers will no longer be required to fulfill requirements specified in their existing offers.

District hospital in Żywiec, as Complex of Healthcare Facilities, was added to list of hospitals published by the Minister of Health. This means the possibility of entering into a contract with NFZ automatically, without the necessity of participating in competition procedure. This kind of financial stability may positively affect the long-term nature of PPP not only in case of construction of District Hospital in Żywiec but also for later activities connected to maintenance and management of the medical facility. 


\section{Conclusions}

The project of construction of District Hospital in Żywiec is first in Poland example of public-private partnership venture in the field of healthcare. The significance of promotion of PPP as the formula for modernization of hospitals and development of new healthcare facilities should be noted. Some public entities are not capable of performing public tasks entrusted to them by the legislator. Lack of financial capabilities of public entities to conduct such expensive projects should encourage them to seek alternative solutions, such as cooperation of private and public sectors in form of PPP.

Due to the contractual system of financing health care in Poland based on one-year or three-year agreements with NFZ, the possibility of modification of contracts for medical services provided by healthcare operators selected within the PPP should be considered, with regard to the long-term involvement of the private partner in the execution of given project.

Furthermore, both in case of District Hospital in Żywiec and in other ventures, particular attention must be drawn to the necessity of public consultations in reference to the realization of supra-local ventures. Lack of consultations in respect of the location of the project may lead to social concerns and discontent despite the need and general acceptance for execution of given venture.

\section{References}

Bayer, K.: Wiedza jako kluczowy zasób w nowej gospodarce (Knowledge as a key resource in the new economy), Studia i Praca (Studies and Work) no. 3 (2011).

Bem, M., Bogdanowicz, P., Piotrkowski, P.: Ustawa o partnerstwie publiczno-prywatnym. Komentarz (Act on public-private partnership. Comment), Warszawa: C.H. Beck, 2014.

Brzozowska, K.: Partnerstwo publiczno-prywatne. Przesłanki, możliwości, bariery (Public-private partnership. Premises, possibilities, barriers), Warszawa: CeDeWu, 2006.

Dyczkowski, A.: Nowy Leksykon PWN (The new PWN Lexicon), Warszawa: PWN, 1998.

Gonet, W.: Komentarz do ustawy o partnerstwie publiczno-prywatnym. Wzory umów i pism (Commentary to the Act on public-private partnership. Patterns of contracts and letters), Warszawa: LexisNexis, 2009.

Herbst, I., Jadach-Sepioło, A.: Raport ze studiów przypadku PPP sporządzony na potrzeby “Analizy potencjału podmiotów publicznych i przedsiębiorstw do realizacji projektów Partnerstwa Publiczno-Prywatnego" dla Polskiej Agencji Rozwoju Przedsiębiorczości (Report on PPP case studies prepared for the needs of "Analysis of the potential of public entities and enterprises for the implementation of Public-Private Partnership projects" for the Polish Agency for Enterprise Development), Warszawa 2012. 
Ocena Skutków Regulacji do Projektu rozporządzenia Ministra Zdrowia zmieniającego rozporządzenie w sprawie ogólnych warunków umów o udzielanie świadczeń opieki zdrowotnej (Evaluation of the Effects of Regulation to the draft Regulation of the Minister of Health amending the Regulation on general conditions of contracts for the provision of healthcare services no. 546.

Partnerstwo publiczno-prywatne. Poradnik (Public-private partnership. Guide), UZP, Warszawa 2010 .

Urbanowski, M. et al.: Raport z poprawności przeprowadzenia procedury wyboru partnera prywatnego dla przedsięwzięcia "Budowa Szpitala Powiatowego w Żywcu" pod kątem wykorzystania dobrych praktyk w projektach hybrydowych oraz projektowania rozwiązań na przyszłą perspektywę budżetową (Report on the correctness of the procedure for selecting a private partner for the project "Construction of a Poviat Hospital in Żywiec" in terms of using good practices in hybrid projects and designing solutions for the future budget perspective), Warszawa 2011.

PL: Act of 27 August 2009, on Public Finance, as amended.

PL: Act of 19 December 2008, on Public-Private Partnership, as amended.

PL: Act of 2 July 2004, on The Freedom of Economic Activity, as amended.

PL: Regulation of the Minister of Health of 2 February 2011 on the requirements that should be met in terms of professional and sanitary premises and facilities of the healthcare facility.

PL: Decree of the Minister of Health of 2 February 2011 on professional and sanitary requirements placed on premises and equipment in healthcare facilities.

PL: District Council in Żywiec: XXXV/317/09.

PL: District Council in Żywiec: XLIII/401/2010.

Draft no. 1180, justification to the draft Act on public-private partnership.

Draft no. 1322, justification to the Act amending the Act on health care services financed from public funds.

website of InterHealth Canada. www.interhealthcanada.com.

website of Starost's Office in Żywiec. www.starostwo.zywiec.pl. 